\title{
Postępowanie w chorobie Leśniowskiego-Crohna - step-up czy top-down?
}

\begin{abstract}
STRESZCZENIE
$\mathbf{N}$ ieswoiste choroby zapalne jelit (NChZJ) wyróżniają się przewlekłym i nawrotowym charakterem. Prowadzą do licznych powikłań i przyczyniają się do znacznego obniżenia jakości życia chorujących. Etiologia NChZJ nadal nie została precyzyjnie określona, dlatego leczenie skupia się na indukowaniu remisji i jej utrzymaniu. W tym celu stosuje się taktykę "step-up", polegającą na stopniowym włączaniu coraz to silniejszych leków wraz z nasilaniem objawów zapalenia. Badania z ostatnich lat sugerują jednak, że rozpoczęcie leczenia od silnych leków biologicznych, nazywane strategią "top-down", może być znacznie bardziej efektywne i przyczyniać się do zmiany przebiegu choroby. Celem poniższego artykułu jest opis obydwu strategii, porównanie ich skuteczności oraz zastosowania klinicznego.
\end{abstract}

\section{WPROWADZENIE}

Choroba Leśniowskiego-Crohna (ChLC) należy do grupy chorób o podłożu zapalnym, na którą na świecie rocznie zapada średnio 3-20/100 000 osób, a w ostatnich latach obserwowany jest wzrost liczby zachorowań [1]. Pomimo intensywnych badań etiologia ChLC nadal nie została w pełni poznana, jednakże ustalono, że na rozwój choroby wpływają predyspozycje genetyczne, środowisko, zaburzenia mikrobiomu jelitowego czy integralności błony śluzowej jelit [2]. ChLC ma charakter przewlekły, z występującymi naprzemiennie okresami remisji i nawrotów, podczas których niezbędne jest zastosowanie leczenia farmakologicznego. Fakt, że podłoże choroby nadal nie zostało poznane sprawia, że terapia jest bardzo utrudniona i skupia się jedynie na łagodzeniu symptomów. Do metod stosowanych w leczeniu ChLC należą terapia "step-up" i terapia ",top-down". Pierwsza z wymienionych strategii polega na włączaniu do leczenia leków o najmniejszej szkodliwości, a w razie braku efektu leczniczego bądź występowania działań niepożądanych, podawaniu leków o silniejszym działaniu terapeutycznym. Założeniem terapii "top-down" jest od samego początku wprowadzanie leków o silnym działaniu. Związki wykorzystywane w tych strategiach to: pochodne kwasu 5-aminosalicylowego (5-ASA), glikokortykostereoidy (GKS), związki immunosupresyjne oraz leki biologiczne [3]. Mimo tego, iż obecnie stosowane są określone schematy leczenia, to nadal nie opracowano optymalnej strategii, która zapewniłaby długotrwałą remisję niwelując objawy kliniczne, jednocześnie nie powodując poważnych powikłań [4].

\section{TERAPIA "STEP-UP”}

Obecnie standardem $\mathrm{w}$ terapii ChLC jest strategia „step-up", która polega na rozpoczęciu leczenia środkami o stosunkowo mniejszej skuteczności, jednak również o najmniejszej szkodliwości i w przypadku braku poprawy stanu klinicznego podawaniu następczym coraz to silniejszych leków. American College of Gastroenterology (ACG) zaleca przystąpienie do leczenia pochodnymi kwasu 5-aminosalicylowego (5-ASA) lub antybiotykami (np. metronidazol) [4]. Rekomendacje te są poparte wynikami badań klinicznych. Sulfasalazyna okazała się skuteczniejsza od placebo w badaniach na pacjentach z ChLC o umiarkowanym nasileniu [5]. Czas terapii wynosił 16 tygodni, co pozwoliło na osiągnięcie remisji u około połowy pacjentów. W badaniach porównujących metronidazol z sulfasalazyną wykazano podobną skuteczność dla obu leków, jednakże obydwa leki charakteryzowała większa skuteczność w przypadku stanu zapalnego obejmującego przynajmniej częściowo jelito grube $\mathrm{w}$ porównaniu $\mathrm{z}$ izolowanym zapaleniem jelita cienkiego, co znajduje uzasadnienie w budowie sulfasalazyny, która łączy 5-ASA i sulfapirydynę. Obecność sulfapirydyny zapobiega wchłonięciu 5-ASA w żołądku i jelicie cienkim, natomiast w okrężnicy wskutek aktywności azoreduktazy wytwarzanej przez bakterie następuje rozszczepienie 5-ASA od

\section{Marta Piotrowska,}

lek. Julia Krajewska,

prof. dr hab. Jakub Fichna,

dr Kinga Majchrzak ${ }^{\varpi}$

Zakład Biochemii, Wydział Lekarski, Uniwersytet Medyczny w Łodzi

https://doi.org/10.18388/pb.2019_288

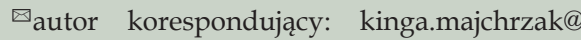
umed.lodz.pl

Słowa kluczowe: choroba Leśniowskiego-Crohna, glikokortykosteroidy, TNF-a, leki biologiczne

Wykaz skrótów: ACG - American College of Gastroenterology, 5-ASA - kwas 5-aminosalicylowy, AZA - azatiopryna, ChLC - choroba Leśniowskiego - Crohna, EMA - European Medicines Agency, FDA - Food and Drug Administration, GKS - glikokortykosteroidy, IFX - infliksimab, 6-MP - 6-merkaptopuryna, NChZJ - nieswoiste choroby zapalne jelit, WZJG - wrzodziejące zapalenie jelita grubego

Finansowanie: Praca finansowana $\mathrm{w}$ ramach działalności statutowej Zakładu Biochemii (503/1-156-04/503-11-001-19-00). 
sulfapirydyny. W związku z tym sulfalazyna okazuje się skuteczna w leczeniu zapalenia jelita grubego i ChLC. Według najnowszych zaleceń Food and Drug Administration (FDA) oraz European Medicines Agency (EMA) stosowanie ciprofloksacyny w leczeniu ChLC powinno być ograniczone do szczególnych przypadków, z uwagi na możliwość wystąpienia objawów niepożądanych [3]. Jeśli takie leczenie nie przyniesie zakładanych efektów terapeutycznych lub występujące objawy nasilą się, w dalszym postępowaniu powinny zostać wdrożone glikokortykosteroidy (GKS). W terapii z udziałem GKS (hormonów steroidowych) wykorzystuje się ich właściwości przeciwzapalne, które polegają na hamowaniu uwalniania mediatorów zapalenia oraz histaminy, migracji fibroblastów i leukocytów, syntezy leukotrienów, kolagenu i PAF, hamowanie aktywności limfocytów T. GKS wykazują właściwości immunosupresyjne, przeciwalergiczne, regulują przemiany białek, węglowodanów, tłuszczów. Najczęściej stosowane w leczeniu ChLC to: prednizon, metyloprednizolon, prednizolon, budesonid. Badania kliniczne wykazały, iż nawet $50-70 \%$ pacjentów z ciężką postacią ChLC uzyskało remisję choroby po 8-12 tygodniach leczenia prednizonem w dawce 0,5-0,75 mg/kg m. c. lub jego równoważnikiem [5]. Według Benchimol EL w systematycznym przeglądzie Cochrane Library stwierdzono, że GKS są bardziej skuteczne w indukcji remisji u pacjentów z ChLC niż 5-ASA, ale często wywołują działania niepożądane. Potrzebne są dalsze badania dotyczące optymalizacji czasu leczenia przy udziale GKS w celu maksymalizacji ich skuteczności [6]. Z kolei Steinhart AH opisuje, że zastosowanie GKS u pacjentów w fazie wyciszenia objawów ChLC nie zmniejsza ryzyka nawrotu choroby w ciągu 24 tygodni obserwacji [7]. Do najpoważniejszych działań niepożądanych GKS zalicza się: zastoinową niewydolność serca, ryzyko wystąpienia zakrzepów, nadciśnienie tętnicze i wtórne zahamowanie reaktywności osi przysadkowo-nadnerczowej Dodatkowo stosowanie sterydów powoduje osteopenię i osteroporozę prowadząc do patologicznych złamań kości długich. Jednakże, u tzw. pacjentów steroidozależnych leki te są w stanie wywołać remisję choroby, której podtrzymanie wymaga podawania kolejnych związków o działaniu immunosupresyjnym tj. azatiopryny (AZA) i 6-merkaptopuryny (6-MP) lub metotrexatu [8].

Pacjentom z ChLC, którzy są oporni na leczenie metodami konwencjonalnymi, a także w przypadkach, gdy w przebiegu choroby powstają przetoki podaje się infliksimab (IFX), będący inhibitorem czynnika martwicy nowotworu (ang. tumor necrosis factor alpha, TNF-a) - cytokiny odpowiedzialnej za aktywność limfocytów i regulację metabolizmu innych komórek [9]. Wykazano, iż po 4 tygodniach terapii IFX w dawce $5 \mathrm{mg} / \mathrm{kg} \mathrm{m}$. c. nawet u $80 \%$ pacjentów obserwuje się poprawę stanu zdrowia, natomiast ponad $50 \%$ pacjentów osiąga remisję choroby [5].

\section{TERAPIA ,TOP-DOWN"}

Mimo, iż wyżej opisane schematy leczenia są dostosowywane do potrzeb pacjentów, to ich efektywność nie jest zadowalająca [4]. Z tego powodu zaproponowano nową strategię terapii polegającą na rozpoczęciu leczenia

Tabela 1. Porównanie działania GKS i IFX.

\begin{tabular}{|c|c|c|}
\hline Lek & GKS & IFX \\
\hline $\begin{array}{l}\text { Molekularny punkt uchwytu } \\
\text { (miejsce docelowe) }\end{array}$ & Wewnątrzkomórkowe receptory steroidowe [31] & $\begin{array}{l}\text { Czynnik martwicy } \\
\text { nowotworów (TNF-a) [32] }\end{array}$ \\
\hline Mechanizm działania & $\begin{array}{l}\text { Działanie przeciwzapalne poprzez modulację ekspresji genów: } \\
\text { 1. Hamowanie uwalniania mediatorów zapalenia oraz histaminy. } \\
\text { 2. Zatrzymanie migracji fibroblastów i leukocytów. } \\
\text { 3. Blokowanie syntezy leukotrienów, kolagenu i PAF. } \\
\text { 4. Hamowanie aktywności limfocytów T. } \\
\text { Właściwości immunosupresyjne i przeciwalergiczne. } \\
\text { Regulacja przemian białek, węglowodanów, tłuszczów }\end{array}$ & Blokowanie czynnika TNF-a [30] \\
\hline Początek działania & Opóźniony [31] & Natychmiastowy [32] \\
\hline Działania niepożądane & $\begin{array}{l}\text { 1. Zatrzymanie wody i sodu w organizmie } \\
\text { 2. Hipokaliemia } \\
\text { 3. Zastoinowa niewydolność serca, ryzyko wystąpienia zakrzepów } \\
\text { 4. Nadciśnienie tętnicze } \\
\text { 5. Osłabienie i zmniejszenie masy mięśniowej, miopatia posteroidowa } \\
\text { 6. Choroba wrzodowa (perforacje, krwotok) } \\
\text { 7. Zapalenie trzustki } \\
\text { 8. Wybroczyny i wylewy podskórne } \\
\text { 9. Wzmożona potliwość } \\
\text { 10. Trądzik, rozstępy, utrudnione gojenie ran } \\
\text { 11. Zawroty i bóle głowy, zaburzenia psychiczne, drgawki } \\
\text { 12. Objawy rzekomego guza mózgu } \\
\text { 13. Zaburzenia miesiączkowania } \\
\text { 14. Jatrogenny zespół Cushinga } \\
\text { 15. Wtórne zahamowanie reaktywności osi przysadkowo-nadnerczowej } \\
\text { 16. Zmniejszenie tolerancji węglowodanów aż do wystąpienia cukrzycy } \\
\text { 17. Zaćma, wzrost ciśnienia wewnątrzgałkowego, jaskra wtórna } \\
\text { 18. Zwiększona podatność na zakażenia } \\
\text { 19. Osteoporoza, osteopenia [29] }\end{array}$ & $\begin{array}{l}\text { 1. Obrzęk twarzy } \\
\text { 2. Nadmierny zarost } \\
\text { 3. Nocne poty } \\
\text { 4. Bezsenność, nadpobudliwość } \\
\text { 5. Wysokie ciśnienie krwi } \\
\text { 6. Cukrzyca } \\
\text { 7. Osteoporoza } \\
\text { 8. Zaćma, jaskra } \\
\text { 9. Zwiększone ryzyko zakażeń [29] }\end{array}$ \\
\hline
\end{tabular}


w początkowej fazie rozwoju choroby od leków biologicznych, immunosupresantów lub ich połączenia [10]. Taki sposób leczenia nazywa się terapią "top-down" i jego założeniem jest zminimalizowanie czasu przyjmowania leków oraz uniknięcie podawania pacjentom GKS, które powodują wiele działań niepożądanych. Porównanie działania GKS i IFX z uwzględnieniem działań niepożądanych znajduje się w Tabeli 1.

Wyniki analiz odnoszących się do skuteczności terapii "top-down" są niejednoznaczne. Przegląd 19 badań, w których stosowano tę strategię wykazał, że podczas gdy łączone stosowanie leków biologicznych i immunomodulujących skutecznie poprawiało stan pacjentów, leczenie wyłącznie jedną grupą ww. leków nie przynosiło jednoznacznie lepszych rezultatów niż terapia "step-up”. Także $\mathrm{w}$ populacji pediatrycznej wyniki były nieprzekonywujące [12]. Choć należy wystrzegać się stosowania niewystarczająco intensywnego leczenia lub przewlekłej steroidoterapii, zbyt agresywne podejście (które może mieć miejsce w strategii "top-down") wiąże się z wysokim ryzykiem efektów ubocznych nie przynosząc dodatkowych korzyści, a w konsekwencji szkodzi pacjentom [10].

\section{PORÓWNANIE "STEP-UP” I "TOP-DOWN"}

Belgian Inflammatory Bowel Diseases Research Group razem z Gut Club of North Holland przeprowadzili badania kliniczne $\mathrm{w}$ celu porównania obu strategii i rozstrzygnięcia, która $\mathrm{z}$ nich jest bardziej korzystna [11]. W tym celu wybrali 129 osób z ChLC, które zostały świeżo zdiagnozowane i nigdy nie były leczone GKS ani immunosupresantami. Strategii „step-up" poddano 64 pacjentów, a strategii "top-down" 65. Grupy zostały dobrane tak, aby w każdej znajdowała się podobna liczba osób ze względu na płeć, wiek, wagę oraz lokalizację i stopień aktywności zapalenia.

Pacjenci leczeni strategią „step-up" otrzymali GKS i tylko w przypadku nawrotu choroby podawano im kolejną dawkę. Jeśli pojawiło się następne zaostrzenie objawów lub pacjenci okazali się sterydooporni - aplikowano AZA. Gdy po trzech miesiącach leczenia przy użyciu AZA następował nawrót lub aktywność choroby była przewlekła, do terapii włączany był IFX. W przypadku alergii lub nietolerancji AZA leczeni otrzymywali metotrexat.

Randomizowanej grupie pacjentów leczonej metodą "top down" trzykrotnie (na początku leczenia oraz po upływie dwóch i sześciu tygodni od jego rozpoczęcia) podano IFX razem z AZA. Jeśli po którymś z trzech podań pojawił się nawrót choroby, przy każdym zaostrzeniu podawana była dodatkowa dawka IFX. Wyłącznie pacjentom z wyjątkowo opornym CD dołączano do leczenia GKS.

W grupie pacjentów którzy nie mieli aktualnie wskazań do zażywania GKS po 6 miesiącach zaobserwowano remisję u $75 \%$ leczonych strategią "top-down" i $48 \%$ poddanych terapii "step-up", a po 12 miesiącach odpowiednio u 77 i $47 \%$ badanych. Zaobserwowano, że w 10 tygodniu badania objawy ustąpiły aż u 60\% leczonych "top-down".
Ocenie poddano również stan błony śluzowej jelita. Redukcję zmian wrzodowych zanotowano u $57 \%$ pacjentów "top down" i u 21\% pacjentów "step-up" [13].

Każda z wymienionych strategii ma zarówno wady, jak i zalety. GKS wywołują remisję choroby, ale nie utrzymują jej, co wiąże się z koniecznością podawania dodatkowych leków aż połowie pacjentów po upływie roku leczenia [14]. Mimo, że GKS prowadzą do ustąpienia objawów klinicznych to efekt ich działania nie jest długotrwały, ponieważ nie wpływają na poprawę stanu błony śluzowej jelita. Ponadto, u pacjentów stosujących terapię GKS może wykształcić się sterydozależność lub sterydooporność [15]. U pacjentów sterydozależnych stosowane są leki z grupy tiopuryn, AZA i 6-MP , ale aby uzyskać efekt terapeutyczny trzeba je podawać nawet przez 12-16 tygodni [16]. Warto dodać, iż również ta grupa leków wiąże się ze znacznymi działaniami niepożądanymi. Oprócz powikłań wynikających z obniżenia odporności, po użyciu AZA rejestrowano przypadki zapalenia ślinianek [16] czy hepatotoksyczność prowadzącą do cholestazy [17].

Badania przeprowadzone przez Group d'Etude Therapeutiqe des Affectoines Inflammatories Digestives (GETAID) wykazały, że z $90 \%$ pacjentów leczonych terapią "step-up", u których uzyskano poprawę w zakresie objawów klinicznych jedynie $29 \%$ wykazało polepszenie w obrazie endoskopowym jelita [17]. Wynika z tego, że strategia "step-up" skupia się na kuracji symptomów przy jednoczesnym braku działania terapeutycznego na stan błony śluzowej jelita.

Ponadto, w przypadku nieskuteczności strategii „step-up" i zaistnienia konieczności leczenia chirurgicznego zaobserwowano, że u pacjentów z zainstalowanym wewnętrznym zbiornikiem jelitowym, aż w $45 \%$ dochodzi do jego zapalenia [18] i aż połowa osób poddanych zabiegowi wymaga powtórzenia interwencji chirurgicznej [19].

Naprzeciw tym problemom wychodzi terapia "top-down", która w przeciwieństwie do strategii "step-up", zapewnia długotrwałą remisję choroby. Jest to możliwe do osiągnięcia dzięki szybkiemu zniwelowaniu procesu zapalnego, zanim dojdzie do nieodwracalnych zmian w jelicie. Taktyka "top-down" skraca czas leczenia i zapewnia lepsze utrzymanie remisji choroby, zapobiegając komplikacjom związanym z uszkodzeniami jelit. Wczesne podanie IFX zapobiega rozwojowi przetok i niedrożności, dzięki czemu unika się zabiegów chirurgicznych, które są niekomfortowe dla pacjentów. Ograniczenie dni spędzonych w szpitalu oraz liczby operacji, które generują aż 80\% kosztów związanych z leczeniem ChLC [20], wydaje się być również zaletą terapii "top-down". Kluczem do sukcesu terapeutycznego w NChZJ wydaje się być działanie poprawiające i zachowujące prawidłowy stan śluzówki jelit, nie zaś działanie wyłącznie objawowe.

Z drugiej strony, badania pokazują, że 55\% pacjentów po roku leczenia konwencjonalnymi metodami utrzymuje stałą remisję [21], dlatego stosowanie agresywnej terapii u wszystkich diagnozowanych wydaje się być zbędnym 
narażaniem ich na poważne skutki uboczne. W doborze odpowiedniej strategii mógłby pomóc podział pacjentów ze względu na postać choroby i wyodrębnienie grupy osób wymagającej agresywnego leczenia. Jednakże nadal nie zostały zidentyfikowane markery pozwalające na efektywną i rzetelną ocenę zaawansowania choroby [22]. U dużej części pacjentów już w chwili diagnozy występują poważne komplikacje $\mathrm{w}$ postaci perforacji ściany jelita [23]. U takich pacjentów, po zajściu nieodwracalnych uszkodzeń śluzówki jelit, zastosowanie terapii biologicznej nie miałoby już wpływu na dalszy bieg ChLC. Kolejnym problemem związanym z terapią "top-down" jest fakt, że IFX jest nie tylko przeciwciałem monoklonalnym przeciwko czynnikowi TNF-a, ale także prowadzi do apoptozy komórek wykazujących ekspresję TNF-a na swojej powierzchni, przez co osoby leczone IFX są narażone na bardzo poważne infekcje [24], również tzw. infekcje oportunistyczne, charakterystyczne dla pacjentów z niedoborami odporności, również na skutek leczenia immunosupresyjnego. Tego typu powikłania bardzo dobrze obrazuje przypadek opisany we Włoszech, kiedy to 48-letni pacjent z ChLC leczony przez około 4 miesięcy IFX, zgłosił się do szpitala z objawami niewydolności oddechowej, limfopenią, gorączką oraz niedożywieniem energetyczno-białkowym. U pacjenta stwierdzono gruźlicę płuc współwystępującą z inwazyjną aspergilozą płucną [25].

Jako jedną z głównych zalet terapii "top-down” wymienia się redukcję kosztów leczenia. Jak się jednak okazuje, $80 \%$ kosztów związanych z leczeniem chorych na ChLC generują interwencje chirurgiczne i hospitalizacja [20], aczkolwiek ponad $50 \%$ chorujących ich nie potrzebuje [21]. Oznacza to, że przy wcześniejszym zastosowaniu leków biologicznych ogólne koszty leczenia mogą być w rzeczywistości mniejsze w związku z mniejszą ilością pobytów w szpitalu, operacji i leczenia powikłań.

Warto również dodać, iż obecnie na rynku farmaceutycznym funkcjonują nowe leki biologiczne, o podobnym działaniu jak IFX, np. adalimumab. Adalimumab jest rekombinowanym ludzkim przeciwciałem monoklonalnym skierowanym przeciw TNF-a. Food and Drug Administration zakwalifikowała adalimumab do leczenia ChLC w 2007 r. [25]. Lekami o odmiennym działaniu niż IFX są m.in. ustekinumab i vedolizumab. Ustekinumab jest przeciwciałem monoklonalnym, które z dużą swoistością wiąże się z podjednostką białkową p40 wspólną dla cytokin- IL-12 i IL-23, które odgrywają rolę w patogenezie ChLC $[26,27]$. Vedolizumab to selektywne przeciwciało monoklonalne wiążące się z integryną a $4 \beta 7$, co w sposób selektywny hamuje migrację leukocytów ze światła naczyń krwionośnych do miejsca objętego stanem zapalnym w przewodzie pokarmowym [28]. Oba leki zostały zarejestrowane w Unii Europejskiej do leczenia ChLC (vedolizumab w 2014r. ustekinumab w 2016 r.) i w listopadzie 2019 r. zostały w Polsce włączone przez Ministerstwo Zdrowia do programu lekowego [29].

\section{PODSUMOWANIE}

Z przedstawionych wyżej danych wynika, że terapia "top-down" rozwiązuje wiele problemów związanych ze stosowaniem leczenia "step-up" i daje nadzieję na lepszą codzienność wielu pacjentom z ChLC. Jednakże wdrażanie jej nie jest odpowiednie dla każdego stopnia zaawansowania ChLC, dlatego $\mathrm{w}$ wyborze strategii powinno się stosować indywidualne podejście uwzględniające zarówno lokalizację, jak i aktywność choroby. Sposób leczenia należy dobierać tak, aby zapewniać najlepszy, z punktu widzenia pacjenta, stosunek skuteczności terapii do ryzyka wystąpienia działań niepożądanych. W tym celu niezbędne są dalsze badania w celu identyfikacji wiarygodnych i prognostycznych biomarkerów farmakogenetycznych, co pozwoliłoby na opracowanie terapii spersonalizowanej [30]. Wybór najlepszej formy leczenia dla pacjentów z ChLC w dzisiejszych czasach jest bardzo trudny. Wymagane są dalsze badania dotyczące indywidualnego doboru terapii dla pacjenta.

\section{PIŚMIENNICTWO}

[1. Molodecky NA (2012) Increasing incidence and prevalence of the inflammatory bowel diseases with time, based on systematic review. Gastroenterology 142(1): 46-54

2. Hanauer SB (2006) Inflammatory bowel disease: epidemiology, pathogenesis, and therapeutic opportunities. Inflamm Bowel Dis 12(1): 3-9

3. Torres J (2019) OUP ECCO Guidelines on therapeutics in Crohn's disease: medical treatment. Journal of Crohn's and Colitis doi: 10.1093/ ecco-jcc/jjz180

4. Dobrowolska-Zachwieja A i Jakubowska-Burek L (2010) Korzyści leczenia biologicznego u osób $\mathrm{z}$ nieswoistymi chorobami zapalnymi jelit. Prz Gastroenterol 5(2): 68-76

5. Lichtenstein GR, Hanauer SB, Sandborn WJ (2009) Management of Crohn's disease in adults. Am J Gastroenterol 104(2): 465-83

6. Benchimol EL (2008) Corticosteroids for induction of remission in Crohn's disease. Cochrane Database Syst Rev 2:CD006792

7. Steinhart AH (2003) Corticosteroids for induction of remission in Crohn's disease. Cochrane Database Syst Rev 4:CD000301

8. Panaccione R, Rutgeerts P, Sandborn WJ, FeaganB, Schreiber S, Ghosh $S$ (2008) Review article: Treatment algorithms to maximize remission and minimize corticosteroid dependence in patients with inflammatory bowel disease. Aliment Pharmacol Ther 28(6): 674-688

9. Idriss HT and Naismith JH (2000) TNF alpha and the TNF receptor superfamily: structure-function relationship(s). Microsc Res Tech 50(3): 184-195

10. Rogler G (2013) Top-down or step-up treatment in Crohn's disease? Dig Dis 31(1): 83-90

11. Mosli M (2017) Risk stratification of patients with crohn's disease: a retrospective analysis of clinical decision making and its impact on long-term outcome. Dig Dis 36(1): 49-55

12. Tsui JJ (2018) Is top-down therapy a more effective alternative to conventional step-up therapy for Crohn's disease? Ann Gastroenterol 31(4): 413-424

13. Baert F, Caprilli R, and Angelucci E (2007) Medical therapy for Crohn's disease: top-down or step-up? Dig Dis 25(3): 260-266

14. Munkholm P, Langholz E, Davidsen M, and Binder V (1994) Frequency of glucocorticoid resistance and dependency in Crohn's disease. Gut 35(3): 360-362

15. Papi C (2007) Long-term outcome of Crohn's disease following corticosteroid-induced remission. Am J Gastroenterol: 102(4) 814-819

16. Chande N, Townsend CM, Parker CE, MacDonald JK (2016) Azathioprine or 6-mercaptopurine for induction of remission in Crohn's disease. Cochrane database Syst Rev 10: CD000545

17. Romagnuolo J, Sadowski DC, Lalor E, Jewell L, and Thomson AB (1998) Cholestatic hepatocellular injury with azathioprine: a case report and review of the mechanisms of hepatotoxicity. Can J Gastroenterol 12(7): 479-483 
18. Modiglianial R (1990) Clinical, biological, and endoscopic picture of attacks of Crohn's disease. Evolution on prednisolone. Groupe d'Etude Therapeutique des Affections Inflammatoires Digestives. Gastroenterology 98(4): 811-818

19. Tremaine WJ, Schroeder KW, Harrison JM, and Zinsmeister AR (1994) A randomized, double-blind, placebo-controlled trial of the oral mesalamine (5-ASA) preparation, Asacol, in the treatment of symptomatic Crohn's colitis and ileocolitis. J Clin Gastroenterol 19(4): 278-282

20. Hay AR and Hay JW (1992) Inflammatory bowel disease: medical cost algorithms. J Clin Gastroenterol 14(4): 318-327

21. Munkholm P, Langholz E, Davidsen M, and Binder V (1995) Disease activity courses in a regional cohort of Crohn's disease patients. Scand J Gastroenterol: 30(7) 699-706

22. Abreu MT (2006) Serologies in Crohn's disease: can we change the gray zone to black and white? Gastroenterology 131(2): 664-667

23. Papi C (2005) Evolution of clinical behaviour in Crohn's disease: predictive factors of penetrating complications. Dig Liver Dis 37(4): 247253

24. Lichtenstein GR (2012) Serious infection and mortality in patients with Crohn's disease: more than 5 years of follow-up in the TREAT registry. Am J Gastroenterol 107(9): 1409-1422
25. Colombel JF (2010) Infliximab, azathioprine, or combination therapy for Crohn's disease. N Engl J Med 362(15): 1383-1395

26. Nelson AL, Dhimolea E, Reichert JM (2010) Development trends for human monoclonal antibody therapeutics. Nat Re. Drug Discov 9(10): 767-74

27. Gisbert JP and Chaparro M (2017) Ustekinumab to treat Crohn's disease. Gastroenterol Hepatol 40(10): 688-698

28. Hinojosa J, Val Del and Barreiro-de Acosta M (2019) Questions and answers about the management of Crohn's disease and ulcerative colitis with vedolizumab. Gastroenterol Hepatol 42(10): 650-656

29. Ministerstwo Zdrowia, Programy lekowe chorób nieonkologicznych, Leczenie Choroby Leśniowskiego-Crohna, https://www.gov.pl/attachment/832e7516-6ced-40f9-ae7a-e66dbcfe8965

30. Voskuil MD (2019) Predicting (side) effects for patients with inflammatory bowel disease: The Promise of pharmacogenetics. World J Gastroeneterol 25(12): 2539-2548

31. Alberts B, Johnson A, Lewis J, Morgan D, Raff M, Roberts K, Walter K (2015) Molecular Biology of the Cell. New York: Garland Science

32. Furuya Y(2007) Theory based analysis of anti-inflammatory effect of infliximab on Crohn's disease, Drug Metabolism and Pharmacokinetics 22(1): 20-25

\section{Strategies in Crohn's disease treatment - "step-up" vs. "top-down"}

\section{Marta Piotrowska, Julia Krajewska, Jakub Fichna, Kinga Majchrzak ${ }^{\square}$}

Department of Biochemistry, Faculty of Medicine, Medical University of Lodz

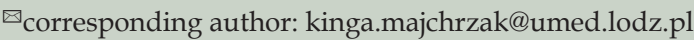

Key words: Crohn's disease, glucocorticosteroids, TNF-a, biological drugs

\section{ABSTRACT}

Inflammatory bowel diseases (IBD) are chronic conditions that lead to serious complications and act to the detriment of quality of patients lives. Etiology of IBD has not been precisely determined but it is assumed that IBD is caused by genetic, immune and environmental factors. The main target in current IBD treatment is the induction and maintenance of remission. The most common strategy in IBD therapy is called "step-up" that is based on gradual introduction of stronger drugs. However, the latest research shows that "top down" strategy is more promising and can change the natural course of the disease. The aim of this article is to discuss both strategies and compare their effectiveness. 